\title{
Halomonas lutea sp. nov., a moderately halophilic bacterium isolated from a salt lake
}

\author{
Correspondence \\ Wen-Jun Li \\ wjli@ynu.edu.cn \\ or \\ liact@hotmail.com
}

\author{
Yun Wang, ${ }^{1} \dagger$ Shu-Kun Tang, ${ }^{2} \dagger$ Kai Lou, ${ }^{1}$ Pei-Hong Mao, ${ }^{3}$ Xiang Jin, ${ }^{3}$ \\ Cheng-Lin Jiang, ${ }^{2} \mathrm{Li}-\mathrm{Hua} \mathrm{Xu}^{2}$ and Wen-Jun $\mathrm{Li}^{2,4}$
}
${ }^{1}$ Xinjiang Institute of Microbiology, Xinjiang Academy of Agricultural Science, Urumqi, Xinjiang 830091, PR China
${ }^{2}$ The Key Laboratory for Microbial Resources of Ministry of Education, PR China, and Laboratory for Conservation and Utilization of Bio-resources, Yunnan Institute of Microbiology, Yunnan University, Kunming 650091, PR China
${ }^{3}$ The Center of Ion Beam Biotechnology, Xinjiang University, Urumqi, Xinjiang 830008, PR China
${ }^{4}$ Guangdong Key Laboratory of Marine Materia Medica, South China Sea Institute of Oceanology, Chinese Academy of Sciences, Guangzhou 510301, PR China

\begin{abstract}
A Gram-negative, moderately halophilic bacterium, designated YIM $91125^{\top}$, was isolated from a salt lake in Xinjiang province, north-west China. The isolate grew at salinities in the range 1-20\% $(\mathrm{w} / \mathrm{v})$ and at $4-45{ }^{\circ} \mathrm{C}$. Optimal growth occurred at $37{ }^{\circ} \mathrm{C}, \mathrm{pH} 7.5$ and $5-10 \%(\mathrm{w} / \mathrm{v}) \mathrm{NaCl}$. Cells were short rods motile by means of single polar flagella. The major fatty acids were $\mathrm{C}_{18: 1} \omega 7 c$, $\mathrm{C}_{16: 0}, \mathrm{C}_{19: 0}$ cyclo $\omega 8 \mathrm{c}$ and $\mathrm{C}_{12: 0} 3-\mathrm{OH}$. The DNA $\mathrm{G}+\mathrm{C}$ content was $60.8 \mathrm{~mol} \%$. The predominant respiratory quinone was $\mathrm{Q}-9$. A comparison of $16 \mathrm{~S}$ rRNA gene sequences revealed its relationship to Halomonas species, its closest neighbours being Halomonas pantelleriensis (95.9\% similarity to the type strain) and Halomonas muralis (95.4\% similarity). On the basis of chemotaxonomic, phylogenetic and phenotypic evidence, strain YIM $91125^{\top}$ represents a novel member of the genus Halomonas, for which the name Halomonas lutea sp. nov. is proposed.

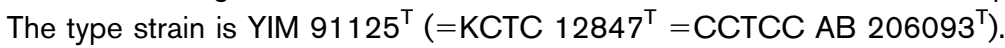

The family Halomonadaceae of the class Gammaproteobacteria currently comprises seven genera, Carnimonas, Chromohalobacter, Cobetia, Halomonas, Halotalea, Modicisalibacter and Zymobacter, and more than half of the taxa in the family have been reclassified according to their heterogeneous features (Franzmann et al., 1988; Mellado et al., 1995; Dobson \& Franzmann, 1996; Arahal et al., 2002a, b). At the time of writing, Halomonas is the largest genus in the family Halomonadaceae and comprises 52 species with validly published names; most of these species were isolated from saline environments (Dobson \& Franzmann, 1996; Mata et al., 2002; Ventosa et al., 1998; Cabrera et al., 2007; Kim et al., 2007; Soto-Ramírez et al., 2007; Wang et al., 2007a, b). Halomonas was described as comprising Gram-negative, aerobic, moderately halophilic bacteria. Some members of this genus have been recognized for their potential use in biotechnology, such as fermented food production, enzyme production (amylases, DNases, lipases, proteases and pullulanases) and the degradation of toxic compounds (Margesin \& Schinner,

†These authors contributed equally to this work.

The GenBank/EMBL/DDBJ accession number for the 16S rRNA gene sequence of strain YIM $91125^{\top}$ is EF674852.
2001; Ventosa \& Neito, 1995; Ventosa et al., 1998; SánchezPorro et al., 2003).

In the course of a programme of screening for halophilic bacteria, a moderately halophilic bacterium belonging to the genus Halomonas was isolated from Ebinur Lake $\left(82^{\circ}\right.$ $35^{\prime}-83^{\circ} 16^{\prime}$ E $44^{\circ} 05^{\prime}-45^{\circ} 08^{\prime} \mathrm{N}$ ), in Xinjiang, north-west China, a highly saline lake that has been a long-term target for the study of element cycling and microbial biota under extremely high-salinity conditions (Cui et al., 2006). The results of a polyphasic characterization of this Halomonas strain, designated YIM $91125^{\mathrm{T}}$, are described here. On the basis of the data presented below, a novel species of the genus Halomonas is proposed to accommodate this isolate.

Strain YIM $91125^{\mathrm{T}}$ was isolated using the dilution plating method on modified ISP 5 medium at $37{ }^{\circ} \mathrm{C}$. This medium contained the following [(1 distilled water $\left.)^{-1}\right]: 1 \mathrm{~g} \mathrm{~L}$ asparagine, $10 \mathrm{~g}$ glycerol, $5 \mathrm{~g}$ yeast extract, $1 \mathrm{~g} \mathrm{~K} \mathrm{KPO}_{4}$, $5 \mathrm{~g} \mathrm{KNO}_{3}, 100 \mathrm{~g} \mathrm{NaCl}$ and $15 \mathrm{~g}$ agar. $\mathrm{NaCl}$ was sterilized separately before being added to the medium. The medium was adjusted to $\mathrm{pH} 7.5$. Strain YIM $91125^{\mathrm{T}}$ was maintained on modified ISP 5 agar slants $(5 \% \mathrm{NaCl}, \mathrm{w} / \mathrm{v} ; \mathrm{pH} 7.5)$ at $4{ }^{\circ} \mathrm{C}$ and as $20 \%(\mathrm{w} / \mathrm{v})$ glycerol suspensions at $-20{ }^{\circ} \mathrm{C}$. Biomass for chemical and molecular studies was obtained 
from cultivation in shaken flasks (about 150 r.p.m.) in modified ISP 5 medium $(5 \% \mathrm{NaCl}, \mathrm{w} / \mathrm{v} ; \mathrm{pH} 7.5)$ at $37{ }^{\circ} \mathrm{C}$ for about 1 week.

Gram staining was carried out using the standard Gram reaction and was confirmed using the $\mathrm{KOH}$ lysis test (Cerny, 1978). Cell motility was confirmed by the presence of turbidity throughout a tube containing semisolid medium (Leifson, 1960). Morphology was examined using transmission electron microscopy ( $\mathrm{H}-800$ microscope; Hitachi) with cells from exponentially growing cultures. Poly- $\beta$-hydroxybutyrate inclusions in cells were stained with Sudan black B (Drews, 1983) and viewed with phasecontrast microscopy. Colony morphology was observed on modified ISP 5 medium containing $5 \% \mathrm{NaCl}(\mathrm{pH} 7.5)$ after incubation at $37{ }^{\circ} \mathrm{C}$ for 3 days. Growth was tested at various temperatures $\left(0,4,10,20,28,37,45\right.$ and $\left.55^{\circ} \mathrm{C}\right)$ on modified ISP 5 medium containing $5 \% \mathrm{NaCl}$. The $\mathrm{pH}$ range for growth was investigated between $\mathrm{pH} 4.0$ and 10.0 (in increments of $1 \mathrm{pH}$ unit) with the buffer system described by $\mathrm{Xu}$ et al. (2005). Liquid cultures were grown in tubes at $37{ }^{\circ} \mathrm{C}$ for $2-3$ weeks, using modified ISP 5 as the basal medium. Tolerance of chlorides of sodium, potassium, magnesium and calcium at concentrations between 0 and $30 \%$ (in increments of $1 \%$ ) were tested using the same basal medium. Catalase activity was determined by assessing bubble production after the addition of a drop of $3 \% \mathrm{H}_{2} \mathrm{O}_{2}$. Oxidase activity was determined by assessing the oxidation of tetramethyl-p-phenylenediamine. The methyl red and Voges-Proskauer tests were performed as described by Lányí (1987). Production of DNase and hydrolysis of casein, starch and Tweens 40 and 80 were tested as described by Smibert \& Krieg (1994). The API 20E system (bioMérieux) was used to determine the following: hydrolysis of gelatin and ONPG, activity of lysine and ornithine decarboxylases, urease and arginine dihydrolase and production of acetoin, $\mathrm{H}_{2} \mathrm{~S}$ and indole. Nitrate reduction and aesculin hydrolysis were tested using the API 20NE system (bioMérieux). The utilization of different compounds as sole carbon, nitrogen and energy sources was determined using GN2 microplates with the Microlog system (Biolog; 95 substrates). Acid production from carbohydrates was determined by using the API $50 \mathrm{CH}$ system (bioMérieux) and enzyme activities were determined by means of the API ZYM system (bioMérieux). Antibiotic susceptibility was determined using the disc diffusion method on agar (Reva et al., 1995).

Strain YIM $91125^{\mathrm{T}}$ comprised Gram-negative, short rods, approximately $0.4-0.7 \mu \mathrm{m}$ wide and $0.6-1.0 \mu \mathrm{m}$ long after cultivation for 3 days at $37{ }^{\circ} \mathrm{C}$ on modified ISP 5 agar containing $5 \% \mathrm{NaCl}(\mathrm{w} / \mathrm{v})$. Cells were motile by means of single polar flagella. On modified ISP 5 agar containing $5 \%$ $\mathrm{NaCl}(\mathrm{w} / \mathrm{v})$, colonies were orange, flat, opaque and mucoid with slightly irregular edges. Cells were oxidase- and catalase-positive. The other physiological and biochemical properties determined for strain YIM $91125^{\mathrm{T}}$ are given in Table 1 and in the species description.

For the analysis of fatty acids, strain YIM $91125^{\mathrm{T}}$ was cultivated at $37^{\circ} \mathrm{C}$ for $48 \mathrm{~h}$ on tryptic soy agar (Difco) containing $5 \% \mathrm{NaCl}$ and investigated as described by Sasser (1990), using the Microbial Identification System (MIDI). Isoprenoid quinones were extracted and purified as described by Komagata \& Suzuki (1987). The purified ubiquinones were dissolved in acetone and separated by reversed-phase HPLC. The predominant respiratory quinone found in strain YIM $91125^{\mathrm{T}}$ was Q-9, similar to members of the genus Halomonas. The fatty acids $(>1 \%)$

Table 1. Differential characteristics of strain YIM $91125^{\top}$ and its closest neighbours in the genus Halomonas

Strains: 1, YIM 91125 ; 2, H. muralis LMG 20969 ${ }^{\mathrm{T}}$; 3, H. pantelleriensis DSM 9661 ${ }^{\mathrm{T}}$; 4, H. desiderata DSM 9502 ${ }^{\mathrm{T}}$; 5 , H. kribbensis KCTC $12584^{\mathrm{T}}$. Data for reference strains are from Heyrman et al. (2002), Romano et al. (1997), Berendes et al. (1996) and Jeon et al. (2007), respectively. +, Positive; -, negative; NA, data not available.

\begin{tabular}{|c|c|c|c|c|c|}
\hline Characteristic & 1 & 2 & 3 & 4 & 5 \\
\hline Cell morphology & Short rods & Rods & Rods & Rods & Cocci or short rods \\
\hline Pigmentation & Orange & Cream & Cream & NA & Yellow-cream \\
\hline $\mathrm{NaCl}$ range $(\%, \mathrm{w} / \mathrm{v})$ & $1-20$ & $0-15$ & $1-15$ & $0-18$ & $1-14$ \\
\hline $\mathrm{pH}$ range & $5.0-9.0$ & $5.5-10.0$ & $6.0-11.0$ & $7.0-11.0$ & $5.5-9.5$ \\
\hline Temperature range $\left({ }^{\circ} \mathrm{C}\right)$ & $4-45$ & $10-35$ & $10-45$ & $10-48$ & $10-40$ \\
\hline \multicolumn{6}{|l|}{ Hydrolysis of: } \\
\hline Aesculin & - & + & + & NA & + \\
\hline Gelatin & - & - & - & - & + \\
\hline Urea & - & - & + & - & - \\
\hline Major fatty acids & $\begin{array}{l}\mathrm{C}_{18: 1} \omega 7 c, \mathrm{C}_{16: 0}, \mathrm{C}_{19: 0} \\
\text { cyclo } \omega 8 c, \mathrm{C}_{12: 0} 3-\mathrm{OH}\end{array}$ & $\begin{array}{l}\mathrm{C}_{18: 1} \omega 7 c, \mathrm{C}_{16: 0} \\
\mathrm{C}_{16: 1} \omega 7 c \text { and/or } \\
\text { iso- } \mathrm{C}_{15: 0} 2-\mathrm{OH}\end{array}$ & NA & $\begin{array}{c}\mathrm{C}_{16: 0}, \mathrm{C}_{16: 1} \omega 7 c \\
\mathrm{C}_{18: 1} \omega 7 c\end{array}$ & $\begin{array}{r}\mathrm{C}_{16: 0}, \mathrm{C}_{19: 0} \text { cyclo } \\
\omega 8 c, \mathrm{C}_{17: 0} \text { cyclo }\end{array}$ \\
\hline
\end{tabular}


were $\mathrm{C}_{18: 1} \omega 7 c(25.1 \%), \mathrm{C}_{16: 0}(17.0 \%), \mathrm{C}_{19: 0}$ cyclo $\omega 8 c$ $(13.6 \%), \mathrm{C}_{12: 0} \quad 3-\mathrm{OH} \quad(10.7 \%), \mathrm{C}_{12: 0} \quad(7.9 \%), \mathrm{C}_{10: 0}$ $(6.0 \%)$ and $\mathrm{C}_{17: 0}$ cyclo (4.6\%). The profile of major fatty acids in strain YIM $91125^{\mathrm{T}}$ was also similar to those of members of the genus Halomonas (Heyrman et al., 2002; Romano et al., 1997; Berendes et al., 1996; Jeon et al., 2007).

To determine the $\mathrm{G}+\mathrm{C}$ content of strain YIM $91125^{\mathrm{T}}$, genomic DNA was prepared according to the method of Marmur (1961). The G+C content of the DNA was determined by reversed-phase HPLC (Mesbah et al., 1989) as $60.8 \mathrm{~mol} \%$.

Extraction of genomic DNA and PCR amplification of $16 \mathrm{~S}$ rRNA gene were done as described by Li et al. (2007). The sequence obtained was compared with reference $16 \mathrm{~S}$ rRNA gene sequences retrieved from GenBank/EMBL by means of a BLAST search. Multiple alignments and calculations of evolutionary distances were carried out using CLUSTAL_X software (Thompson et al., 1997). Gaps at the $5^{\prime}$ and $3^{\prime}$ ends of the alignment were omitted for further analysis. Phylogenetic analyses were performed using three treemaking algorithms: neighbour joining (Saitou \& Nei, 1987), maximum likelihood (Felsenstein, 1981) and maximum parsimony (Fitch, 1971). A neighbour-joining phylogenetic tree was constructed from $K_{\text {nuc }}$ values (Kimura, 1980) using MEGA, version 3.0 (Kumar et al., 2004). The topology of the phylogenetic tree was evaluated using the bootstrap resampling method, with 1000 replicates (Felsenstein, 1985).

An almost-complete 16S rRNA gene sequence was determined for strain YIM $91125^{\mathrm{T}}$. Alignment data showed that strain YIM $91125^{\mathrm{T}}$ had the highest levels of 16S rRNA gene sequence similarity with respect to members of the Gammaproteobacteria, in particular with respect to the genus Halomonas. In the phylogenetic tree based on the neighbour-joining algorithm, strain YIM $91125^{\mathrm{T}}$ clustered together with the type strains of Halomonas kribbensis, Halomonas desiderata, Halomonas muralis and Halomonas pantelleriensis (Fig. 1); this relationship was supported by all of the tree-making methods used in this study. The results of the 16S rRNA gene sequence comparisons clearly demonstrated that strain YIM $91125^{\mathrm{T}}$ was a member of the genus Halomonas. The similarities between the 16S rRNA gene sequence of strain YIM $91125^{\mathrm{T}}$ and those of the type strains of 52 Halomonas species with validly published names ranged from 92.0 to $95.9 \%$. The closest relatives of strain YIM $91125^{\mathrm{T}}$ were the type strains of $H$. pantelleriensis ( $95.9 \%$ sequence similarity) and $H$. muralis (95.4\%).

On the basis of chemotaxonomic and phylogenetic data and some phenotypic features that distinguish the novel isolate from its closest neighbours in the genus Halomonas (Table 1), strain YIM $91125^{\mathrm{T}}$ represents a novel species of the genus Halomonas, for which the name Halomonas lutea sp. nov. is proposed.

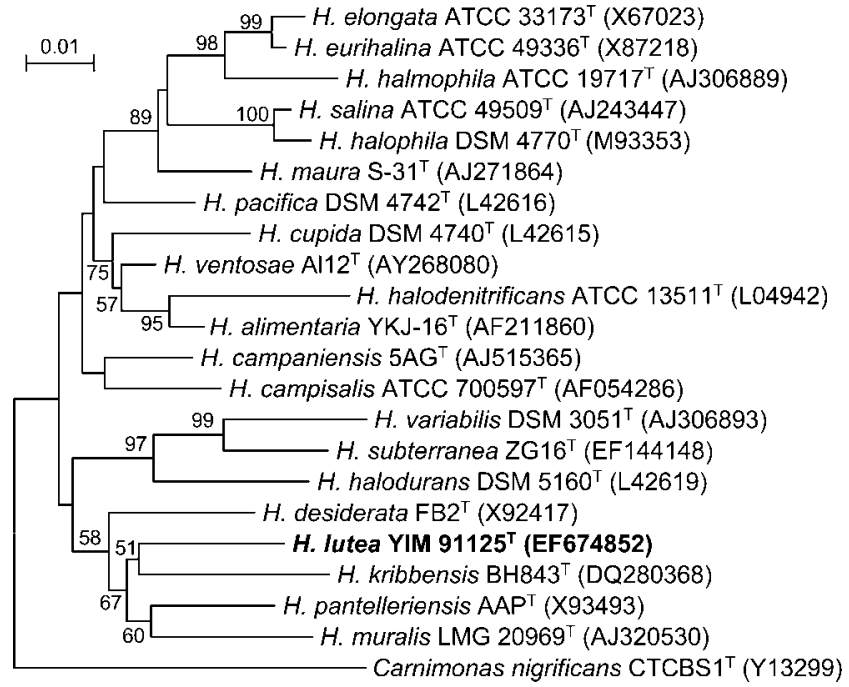

Fig. 1. Neighbour-joining phylogenetic tree, based on 16S rRNA gene sequences, showing the position of strain YIM $91125^{\top}$ among species of genera within the family Halomonadaceae. The sequence of Carnimonas nigrificans $\mathrm{CTCBS}^{\top}$ was used as an outgroup. Bootstrap percentages (based on 1000 resamplings) $>50 \%$ are shown at branching points. Bar, 1 substitution per 100 nucleotide positions.

\section{Description of Halomonas lutea sp. nov.}

Halomonas lutea (lu'te.a. L. fem. adj. lutea orangecoloured).

Cells are aerobic, Gram-negative, short rods and are motile by means of single polar flagella. The type strain is unable to grow on modified ISP 5 medium supplemented with salts containing only $\mathrm{K}^{+}, \mathrm{Mg}^{2+}$ and $\mathrm{Ca}^{2+}$ cations. Growth ranges for temperature, $\mathrm{pH}$ and $\mathrm{NaCl}$ are $4-45^{\circ} \mathrm{C}$, $\mathrm{pH} 5-9$ and $1-20 \%(\mathrm{w} / \mathrm{v}) \mathrm{NaCl}$, with optimal growth at $37{ }^{\circ} \mathrm{C}$, $\mathrm{pH} 7.5$ and $5-10 \%(\mathrm{w} / \mathrm{v}) \mathrm{NaCl}$. Nitrate is reduced. DNase, aesculin, casein, starch and Tweens 40 and 80 are not hydrolysed. Negative for poly- $\beta$-hydroxybutyrate production and in the methyl red and Voges-Proskauer tests. In the API 20E system, the following enzyme activities are recorded as negative: $\beta$-galactosidase, arginine dihydrolase, lysine decarboxylase, ornithine decarboxylase, citrate utilization, urease, gelatinase, indole production from tryptophan, $\mathrm{H}_{2} \mathrm{~S}$ production from sodium thiosulfate and acetoin production from sodium pyruvate. The following substrates are utilized as sole carbon, nitrogen and energy sources (Biolog GN2 system): dextrin, $N$-acetyl-Dglucosamine, DL-arabinose, cellobiose, D-fructose, Dgalactose, $\alpha$-D-glucose, maltose, D-mannitol, methyl $\beta$-Dglucoside, D-psicose, sucrose, trehalose, methyl pyruvate, succinic acid monomethyl ester, acetic acid, formic acid, Dgalacturonic acid, D-gluconic acid, $\alpha$-ketobutyric acid, $\alpha$-ketoglutaric acid, DL-lactic acid, succinic acid, bromosuccinic acid, succinamic acid, L-alaninamide, DL-alanine, L-asparagine, L-aspartic acid, L-glutamic acid, L-proline, 
L-serine, inosine, uridine, 2,3-butanediol, glycerol and glucose 6-phosphate. The remaining substrates of the Biolog GN2 system are not utilized. In the API $50 \mathrm{CH}$ system, acid is produced from glycerol, D-arabinose, Larabinose, D-ribose, D-xylose, L-xylose, D-galactose, Dglucose, D-fructose, L-sorbose, L-rhamnose, D-mannose, D-mannitol, D-sorbitol, aesculin, cellobiose, maltose, Dlactose, melibiose, starch, trehalose, gentiobiose, D-lyxose, D-tagatose, D-fucose, L-fucose, D-arabitol, potassium 2ketogluconate and potassium 5-ketogluconate, but not from erythritol, inositol, D-adonitol, methyl $\beta$-D-xylopyranoside, arbutin, dulcitol, methyl $\alpha$-D-mannopyranoside, methyl $\alpha$-D-glucopyranoside, $N$-acetylglucosamine, amygdalin, salicin, sucrose, inulin, melezitose, raffinose, glycogen, xylitol, turanose, potassium gluconate or Larabitol. In the API ZYM system, alkaline phosphatase, esterase (C4), esterase lipase (C8), cystine arylamidase and naphthol-AS-BI-phosphohydrolase give positive results. Acid phosphatase, lipase (C14), leucine arylamidase, valine arylamidase, trypsin, $\alpha$-galactosidase, $\beta$-galactosidase, $\beta$ glucuronidase, $\alpha$-glucosidase, $N$-acetyl- $\beta$-glucosaminidase, $\beta$-glucosidase, $\alpha$-mannosidase and $\alpha$-fucosidase are negative. The type strain is sensitive to the following antibiotics ( $\mu \mathrm{g}$ per disc, unless indicated otherwise): amoxicillin (10), ampicillin (10), chloramphenicol (30), ciprofloxacin (5), erythromycin (15), gentamicin (10), neomycin (30), netilmicin sulfate (30), norfloxacin (10), novobiocin (30), penicillin $G(10)$, rifampicin (5), streptomycin sulfate (10), tetracycline (30), tobramycin (10), trimethoprim/sulfonamides (23.7/1.25) and vancomycin (30). Resistance is exhibited only to amikacin $(30 \mu \mathrm{g})$ and lincomycin $(2 \mu \mathrm{g})$. Q-9 is the predominant ubiquinone. The major cellular fatty acids are $\mathrm{C}_{18: 1} \omega 7 c, \mathrm{C}_{16: 0}, \mathrm{C}_{19: 0}$ cyclo $\omega 8 c$ and $\mathrm{C}_{12: 0}$ $3-\mathrm{OH}$. The DNA $\mathrm{G}+\mathrm{C}$ content of the type strain is $60.8 \mathrm{~mol} \%$.

The type strain, YIM $91125^{\mathrm{T}}\left(=\mathrm{KCTC} 12847^{\mathrm{T}}=\right.$ CCTCC $A B 206093^{\mathrm{T}}$ ), was isolated from a salt lake in Xinjiang Province, north-west China.

\section{Acknowledgements}

We are grateful to Dr Jean Euzéby for his help with nomenclature. This research was supported by the National Basic Research Program of China (no. 2004CB719601), the Key Project of the Chinese Ministry of Education (no. 206139), the National Natural Science Foundation of China (no. 30600001), the Yunnan Provincial International Cooperative Program (no. 2005GH21), the Open Project Program of the Extremophiles Laboratory of Xinjiang (no. XJYS0203-2005-01) and the Youth Technological Innovation Foundation of Xinjiang Academy of Agricultural Science (no. 2007Q07). W.-J.L. was supported by the Program for New Century Excellent Talents in University.

\section{References}

Arahal, D. R., Castillo, A. M., Ludwig, W., Schleifer, K. H. \& Ventosa, A. (2002a). Proposal of Cobetia marina gen. nov., comb. nov., within the family Halomonadaceae, to include the species Halomonas marina. Syst Appl Microbiol 25, 207-211.
Arahal, D. R., Ludwig, W., Schleifer, K. H. \& Ventosa, A. (2002b). Phylogeny of the family Halomonadaceae based on 23S and 16S rDNA sequence analyses. Int J Syst Evol Microbiol 52, 241-249.

Berendes, F., Gottschalk, G., Heine-Dobbernack, E., Moore, E. R. B. \& Tindall, B. J. (1996). Halomonas desiderata sp. nov., a new alkaliphilic, halotolerant and denitrifying bacterium isolated from a municipal sewage works. Syst Appl Microbiol 19, 158-167.

Cabrera, A., Aguilera, M., Fuentes, S., Incerti, C., Russell, N. J., Ramos-Cormenzana, A. \& Monteoliva-Sánchez, M. (2007). Halomonas indalinina sp. nov., a moderately halophilic bacterium isolated from a solar saltern in Cabo de Gata, Almería, southern Spain. Int J Syst Evol Microbiol 57, 376-380.

Cerny, G. (1978). Studies on the aminopeptidase test for the distinction of gram-negative from gram-positive bacteria. Eur $J$ Appl Microbiol Biotechnol 5, 113-122.

Cui, H.-L., Yang, Y., Tohty, D., Zhou, P.-J. \& Liu, S.-J. (2006). Biodiversity of halophilic archaea isolated from two salt lakes in Xin-Jiang region of China. Wei Sheng Wu Xue Bao 46, 171-175 (in Chinese).

Dobson, S. J. \& Franzmann, P. D. (1996). Unification of the genera Deleya (Baumann et al. 1983), Halomonas (Vreeland et al. 1980), and Halovibrio (Fendrich 1988) and the species Paracoccus halodenitrificans (Robinson and Gibbons 1952) into a single genus Halomonas, and placement of the genus Zymobacter in the family Halomonadaceae. Int J Syst Bacteriol 46, 550-558.

Drews, G. (1983). Mikrobiologisches Praktikum, 4th edn. Berlin: Springer (in German).

Felsenstein, J. (1981). Evolutionary trees from DNA sequences: a maximum likelihood approach. J Mol Evol 17, 368-376.

Felsenstein, J. (1985). Confidence limits on phylogenies: an approach using the bootstrap. Evolution 39, 783-791.

Fitch, W. M. (1971). Toward defining the course of evolution: minimum change for a specific tree topology. Syst Zool 20, 406-416.

Franzmann, P. D., Wehmeyer, U. \& Stackebrandt, E. (1988). Halomonadaceae fam. nov., a new family of the class Proteobacteria to accommodate the genera Halomonas and Deleya. Syst Appl Microbiol 11, 16-19.

Heyrman, J., Balcaen, A., De Vos, P. \& Swings, J. (2002). Halomonas muralis sp. nov., isolated from microbial biofilms colonizing the walls and murals of the Saint-Catherine chapel (Castle Herberstein, Austria). Int J Syst Evol Microbiol 52, 2049-2054.

Jeon, C. O., Kim, J. M., Lee, J. R., Lee, G. S., Park, D. J., Lee, J. C., Oh, H. W. \& Kim, C. J. (2007). Halomonas kribbensis sp. nov., a novel moderately halophilic bacterium isolated from a solar saltern in Korea. Int J Syst Evol Microbiol 57, 2194-2198.

Kim, K. K., Jin, L., Yang, H. C. \& Lee, S. T. (2007). Halomonas gomseomensis sp. nov., Halomonas janggokensis sp. nov., Halomonas salaria sp. nov. and Halomonas denitrificans sp. nov., moderately halophilic bacteria isolated from saline water. Int J Syst Evol Microbiol 57, 675-681.

Kimura, M. (1980). A simple method for estimating evolutionary rates of base substitutions through comparative studies of nucleotide sequences. J Mol Evol 16, 111-120.

Komagata, K. \& Suzuki, K. (1987). Lipid and cell-wall analysis in bacterial systematics. Methods Microbiol 19, 161-207.

Kumar, S., Tamura, K. \& Nei, M. (2004). MEGA3: integrated software for molecular evolutionary genetics analysis and sequence alignment. Brief Bioinform 5, 150-163.

Lányí, B. (1987). Classical and rapid identification methods for medically important bacteria. Methods Microbiol 19, 1-67.

Leifson, E. (1960). Atlas of Bacterial Flagellation. London: Academic Press. 
Li, W. J., Xu, P., Schumann, P., Zhang, Y. Q., Pukall, R., Xu, L. H., Stackebrandt, E. \& Jiang, C. L. (2007). Georgenia ruanii sp. nov., a novel actinobacterium isolated from forest soil in Yunnan (China) and emended description of the genus Georgenia. Int J Syst Evol Microbiol 57, 1424-1428.

Margesin, R. \& Schinner, F. (2001). Potential of halotolerant and halophilic microorganisms for biotechnology. Extremophiles 5, 73-83.

Marmur, J. (1961). A procedure for the isolation of deoxyribonucleic acid from microorganisms. J Mol Biol 3, 208-218.

Mata, J. A., Martínez-Cánovas, J., Quesada, E. \& Béjar, V. (2002). A detailed phenotypic characterisation of the type strains of Halomonas species. Syst Appl Microbiol 25, 360-375.

Mellado, E., Moore, E. R. B., Nieto, J. J. \& Ventosa, A. (1995). Phylogenetic inferences and taxonomic consequences of $16 \mathrm{~S}$ ribosomal DNA sequence comparison of Chromohalobacter marismortui, Volcaniella eurihalina, and Deleya salina and reclassification of $V$. eurihalina as Halomonas eurihalina comb. nov. Int J Syst Bacteriol 45, 712-716.

Mesbah, M., Premachandran, U. \& Whitman, W. B. (1989). Precise measurement of the $\mathrm{G}+\mathrm{C}$ content of deoxyribonucleic acid by highperformance liquid chromatography. Int J Syst Bacteriol 39, 159-167.

Reva, O. N., Vyunitskaya, V. A., Reznik, S. R., Kozachko, A. \& Smirnov, V. V. (1995). Antibiotic susceptibility as a taxonomic characteristic of the genus Bacillus. Int J Syst Bacteriol 45, 409-441.

Romano, I., Nicolaus, B., Lama, L., Manca, M. C. \& Gambacorta, A. (1997). Characterization of a haloalkalophilic strictly aerobic bacterium, isolated from Pantelleria Island. Int J Syst Bacteriol 47, 601-602.

Saitou, N. \& Nei, M. (1987). The neighbor-joining method: a new method for reconstructing phylogenetic trees. Mol Biol Evol 4, 406-425.

Sánchez-Porro, C., Martín, S., Mellado, E. \& Ventosa, A. (2003). Diversity of moderately halophilic bacteria producing extracellular hydrolytic enzymes. J Appl Microbiol 94, 295-300.
Sasser, M. (1990). Identification of bacteria by gas chromatography of cellular fatty acids. USFCC Newsl 20, 16.

Smibert, R. M. \& Krieg, N. R. (1994). Phenotypic characterization. In Methods for General and Molecular Bacteriology, pp. 607-654. Edited by P. Gerhardt, R. G. E. Murray, W. A. Wood \& N. R. Krieg. Washington, DC: American Society for Microbiology.

Soto-Ramírez, N., Sánchez-Porro, C., Rosas, S., González, W., Quiñones, M., Ventosa, A. \& Montalvo-Rodriguez, R. (2007). Halomonas avicenniae sp. nov., isolated from the salty leaves of the black mangrove Avicennia germinans in Puerto Rico. Int J Syst Evol Microbiol 57, 900-905.

Thompson, J. D., Gibson, T. J., Plewniak, F., Jeanmougin, F. \& Higgins, D. G. (1997). The CLUSTAL_X windows interface: flexible strategies for multiple sequence alignment aided by quality analysis tools. Nucleic Acids Res 25, 4876-4882.

Ventosa, A. \& Nieto, J. J. (1995). Biotechnological applications and potentialities of halophilic microorganisms. World J Microbiol Biotechnol 11, 85-94.

Ventosa, A., Nieto, J. J. \& Oren, A. (1998). Biology of moderately halophilic aerobic bacteria. Microbiol Mol Biol Rev 62, 504-544.

Wang, Y. N., Cai, H., Yu, S. L., Wang, Z. Y., Liu, J. \& Wu, X. L. (2007a). Halomonas gudaonensis sp. nov., isolated from a saline soil contaminated by crude oil. Int J Syst Evol Microbiol 57, 911-915.

Wang, Y. N., Cai, H., Chi, C. O., Lu, A. H., Lin, X. G., Jiang, Z. F. \& Wu, $X$. L. (2007b). Halomonas shengliensis sp. nov., a moderately halophilic, denitrifying, crude-oil-utilizing bacterium. Int J Syst Evol Microbiol 57, 1222-1226.

Xu, P., Li, W. J., Tang, S. K., Zhang, Y. Q., Chen, G. Z., Chen, H. H., Xu, L. H. \& Jiang, C. L. (2005). Naxibacter alkalitolerans gen. nov., sp. nov., a novel member of the family 'Oxalobacteraceae' isolated from China. Int J Syst Evol Microbiol 55, 1149-1153. 